\title{
How Managers in Poland Use the Principles and Instruments of the Kaizen Philosophy in Their Personal Lives - The Personal Kaizen Approach
}

\author{
DOI: 10.12776/QIP.V24I2.1396
}

Iwona Burka

Received: 2020-02-11 Accepted: 2020-06-24 Published: 2020-07-31

\begin{abstract}
Purpose: The aim of this paper is to show whether and how Polish managers working in the Kaizen/Lean environment, benefit from the knowledge gained during their professional work to develop competences in their personal lives and improve personal productivity. Do they transfer the knowledge gained about lean systems into their private lives and what are the benefits for them?

Methodology/Approach: To answer the research questions raised, the authoress conducted a literature review and a qualitative research - multiple-case studies. As part of the qualitative study, five in-depth interviews were made.

Findings: The literature review and the qualitative research carried out allowed to formulate conclusions, including, i.a., the following: managers transform the knowledge acquired during the training conducted as part of their professional work into their private lives; it is possible to distinguish a number of principles and instruments of the studied concepts that are applied to support the process of developing personal professional and non-professional competences.

Research Limitation/implication: Subjectivity of the analysis, owing to the application of a qualitative approach in the studies.

Originality/Value of paper: The literature review points to a small number of scientific publications connected with the implementation of the Kaizen approach and Lean Management principles and instruments in the process of developing personal competences and improving personal productivity. This publication is the first approach to creating a Personal Kaizen Toolbox.
\end{abstract}

Category: Research paper

Keywords: Kaizen; personal Kaizen; Lean Management; waste; personal improvement 


\section{INTRODUCTION}

"Success in the knowledge economy comes to those who know themselves their strengths, their values, and how they best perform." (Drucker, 2005, p.100)

We are living in an economy that is based on data, information, and knowledge; therefore, we must constantly learn to be able to develop, improve our work, and improve the quality of life. Garvin asked: How can you improve yourself without finding out something new? How to solve problems or improve processes without trying to look at the matter from a different, new perspective? (Garvin, 1993). That is why managers try to constantly develop their competences by designing their own personal development systems, or basing on solutions taken from the literature or training.

One of the approaches as regards Continuous Personal Improvement is Personal Kaizen. The term Personal Kaizen means constantly improving the quality of your personal life and well-being, by means of introducing a series of small, incremental changes (Suarez-Barraza, Ramis-Pujol and Dahlgaard-Park, 2013). We can also define Personal Kaizen as a set of principles and instruments for personal, continuous improvement in order to develop your own competences.

Kaizen is a philosophy of continuous development, improvement, and amelioration and the name derived from the Japanese words: kai ('change') and zen ('good'). Continuous, by definition, means constant, continuing without interruption, and constantly repeating. Thus, Kaizen is an endless process of correction, implemented in little steps (Imai, 2006; 2007; Emiliani, 1998a; Locher, 2012; Liker and Meier, 2011; Maurer, 2007; 2016; Womack and Jones, 2008). Everything can be improved, and improvement is the responsibility of each employee towards the organization (Stoller, 2015, p.65), and each person in relation to each other. Bicheno and Holweg (2009) describe Kaizen on the one hand as a philosophy, and on the other, as a tool set. Kaizen, according to Liker and Hoseus (2009, p.410), is one of the five values of a caring leader. Liker (2005) placed Kaizen among the fourteen management principles which he called the Toyota Way, and Graban (2011) emphasises that all of us (not only leaders) are obliged to constantly look for ways to improve our work. According to Womack and Jones (2008, p.541), the aim of Kaizen is to create more value with less waste.

The assumptions of the Kaizen philosophy may be applied in both the improvement of processes, structures, systems in organisations, but also in our personal life. They can serve the improvement of the quality of life (SuarezBarraza, Ramis-Pujol and Dahlgaard-Park, 2013) and effectiveness of our actions. Although the improvement in Kaizen is implemented in small steps, it brings huge and lasting results in the long term (Imai, 2006). Maurer (2007, p.541) quotes the words of Wooden, an American basketball player and coach: "When you improve a little each day, eventually big things occur. When you improve conditioning a little each day, eventually you have a big improvement in conditioning. Not tomorrow, not the next day, but eventually a big gain is made. 
Don't look for the big, quick improvement. Seek the small improvement one day at a time. That's the only way it happens - and when it happens, it lasts". Confucius, on the other hand, is credited with words that aptly reflect the meaning of Kaizen's philosophy: "It does not matter how slowly you go as long as you do not stop".

The Kaizen philosophy is based to a large extent on the development of the organisation, which is based on the hidden knowledge of employees, knowledge acquired in their non-professional lives. When planning a training and employee development system, and a motivating system to generate improvements, it is worth paying attention to the passions and interests of the employees. The greatest scientific discoveries of the recent decades have been the result of combining knowledge from different, often seemingly unrelated scientific fields. An appropriate approach to planning a training and employee development system influences the competitiveness of the organization and is responsible for its market success (Roberts and McDonald 1995, p.16), and the broader knowledge and interesting interests the employees have, the more efficiently they solve problems and create new solutions.

Kaizen is a philosophy of development, improvement, but it is also a set of tools (Bicheno and Holweg, 2009). The authoress in her considerations has assumed that since organisations that develop their systems, structures, and processes in accordance with Kaizen assumptions, use the so-called Lean Toolbox to identify and minimise waste, the set of principles and tools proposed in the literature may also be used on the path to develop one's own competences and improve the quality of life. Personal Kaizen is a type of individual Kaizen, oriented on the individual (Imai, 2007, p.136), the goal of which is a gradual but continuous improvement of one's productivity and quality of life, by minimising waste, simplifying, applying standards, taking care of one's own work environment, planning and supervising personal goals, learning from mistakes, but above all being familiar with one's own value system. It is a kind of an individual suggestion system that streamlines the process of developing the competencies of a given person, it is a way of life, as Imai (2006) used to say. A human that adheres to the principles of Personal Kaizen - 'Kaizen person', is someone who can change their way of acting at work and beyond it to develop in a stable and lasting way (Suarez-Barraza, Ramis-Pujol and Dahlgaard-Park, 2013).

In her work, the authoress has raised the following research questions:

RQ1. How and in what way do Polish managers use the knowledge gained within their professional work on Kaizen/Lean Management to develop competences in their personal lives and improve their personal productivity?

RQ2. What benefits do Polish managers achieve from implementing Personal Kaizen in their personal lives? 
The authoress has carried out a literature analysis covering selected principles and instruments of the Kaizen approach and the Lean Management concept, in the context of their application as part of improving personal competences and personal development. This analysis was the basis for preparing a questionnaire for in-depth interviews. The authoress has conducted five in-depth interviews with managers who have been working for at least five years in Polish organisations which operate in accordance with the Kaizen/Lean principles.

The results of the literature analysis are included in point 2 , and the results of the case study in point 4 of this elaboration.

\section{PERSONAL KAIZEN PRINCIPLES AND INSTRUMENTS - LITERATURE REVIEW}

The motto of the organisations which operate in the Kaizen spirit and implement the principles and instruments of Lean Management is to work smarter, not harder. Lighter, more effective, more efficient and more pleasant work should be the goal of both the organisation and each of its members - the employees. Many years of practice in organization management has shown that everything can be improved and there is always potential for improvement (Stoller, 2015), however, the most difficult thing is to improve our own activities, consistently develop and constantly strive to improve the quality of our lives. According to the words of Plato, the first and greatest victory is to conquer yourself. Overcoming weaknesses regarding, for example, one's eating habits, is just as difficult as creating a habit of regular reading or learning foreign languages. Paradoxically, the more we have diet books on the market, the more obese people there are in the world (about growing obesity see Keating, Backholer and Peeters 2014). Markovitz (2011) writes that overcoming his own natural tendencies to generate complexity, mess, and chaos is something extremely difficult and requires something more than just a simple, obvious 'recipe' for effectiveness presented in the guides. From the times we were children, our parents had taught us to put things away, clean up after ourselves, do not buy what we do not need, and yet they did not call it $5 \mathrm{~S}$. We buy toilet paper, when we only have one roll left, and yet we do not call this last roll a kanban. Personal Kaizen is not just a set of obvious solutions, but it is also a change of approach to personal development, in which consistency in action is of great importance. The largest number of gym passes is sold in January, and in February few people remember about the New Year's resolution on improving physical fitness. A sudden, big upsurge usually ends in failure. Small steps seem to be an interesting alternative here.

To answer the research questions raised, the authoress began with a scientific literature query. To this end, she analysed scientific journals collected in the Emerald Publishing Scientific Database, in terms of selected principles and instruments of the Kaizen approach and the Lean Management concept, in the context of their application as part of improving personal competences and improving personal productivity. The key words according to which the database 
was searched are shown in Figure 1 and Figure 2. The literature analysis was carried out in January 2019. As a result of the analysis carried out, as well as numerous interviews conducted with managers working in a Lean environment, focused on continuous improvement, the authoress prepared a list of principles and instruments that can be an element of the Personal Kaizen Toolbox.

The literature analysis and the empirical research results enable listing the following principles and instruments of the Personal Kaizen approach (Personal Kaizen Toolbox):

- continuous improvement in accordance with the Kaizen philosophy;

- knowledge about your own value systems;

- eliminating waste, overloading, and irregularities;

- determining (not necessarily written down) own standards and norms;

- taking care of your own workplace, home, in accordance with the $5 \mathrm{~S}$ principles;

- eliminating complicatedness and unnecessary complexity - simplifying the work system and personal processes;

- the art of asking questions, including in-depth question asking (5 Why);

- planning and setting goals;

- designing an appropriate task management system and education system adapted to the predispositions and personal needs;

- $\quad$ using the benefits of visual management (including personal kanban);

- cooperation and teamwork;

- introduction of a systemic approach to problem solving, including the A3 Report and the Ishikawa diagram;

- learning from mistakes, taking care of feedback, reflection, and selfawareness;

- the use of an appropriate system of work breaks and methods of relaxation;

- stimulating and training creativity - because to change something, we have to look at the problem in a different way;

- proper preparation for learning and development (personal Training Within Industry);

- attention management and concentration training to improve effectiveness of actions related to personal development (Suarez-Barraza, Ramis-Pujol and Dahlgaard-Park, 2013; Markowitz, 2011; Imai 2006; Emiliani, 1998a; Maurer, 2007; 2016; Baccarani, Mascherpa and Minozzo, 2013). 


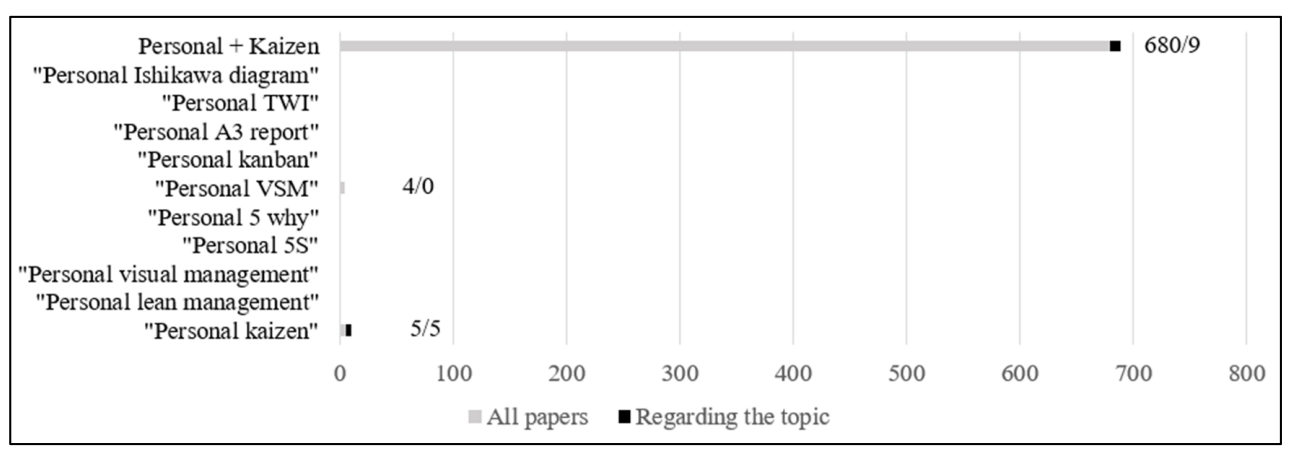

Figure 1 - Graphic Presentation of the Literature Analysis Results Including a List of Key Words

The literature query points to a shortage of scientific publications on the implementation of the Kaizen approach and Lean Management principles and instruments in the process of improving personal competences and improving personal productivity. The sparse publications focus on the process of personal improvement in personal life using the small steps of the Kaizen philosophy. There is even less information about research on the implementation of such instruments as: $5 \mathrm{~S}$, kanban, standardisation work, visual management, value stream analysis, in the process of human personal development. Those who studied the topics were, i.a. Suarez-Barraza, Ramis-Pujol and Dahlgaard-Park (2013) and Emiliani (1998a). The following publications are also recommended: Yoneyama (2007); Baccarani, Mascherpa and Minozzo (2013); Emiliani (1998b).

Taking the above into account, the authoress decided to conduct a qualitative case study among Polish managers, formulating the following research hypotheses:

H1. Polish managers working in the Kaizen/Lean environment, benefit from the knowledge on the principles and instruments of Kaizen/Lean Management gained during their professional work, to develop competences in their personal lives and improve personal productivity.

H2. Polish managers achieve specific benefits related to using the Personal Kaizen approach in their personal lives.

In point 4 of this publication, the authoress presents the results of a qualitative study conducted among Polish managers who work in the Kaizen/Lean environment. 


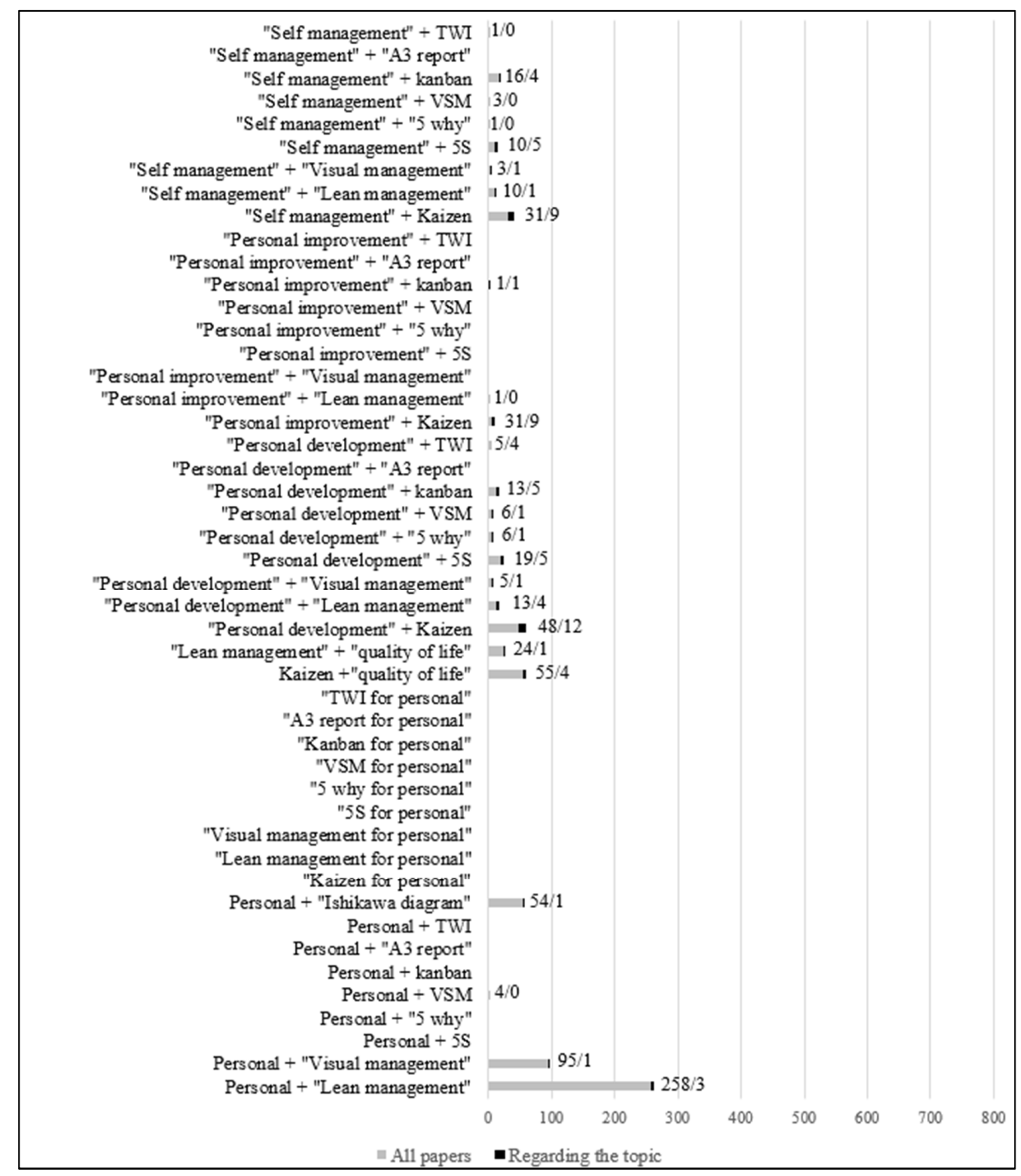

Figure 2 - Graphic Presentation of the Literature Analysis Results Including a List of Key Words

\section{METHODOLOGY}

The implementation of principles and instruments of Kaizen philosophy is more and more popular in Poland. A lot of training in this field is conducted in organisations. However, should the benefits of participating in training only translate into professional work?

In connection with the fact that the research questions start with the question: "How?" and "What?", the authoress decided on qualitative research (multiple- 
case study) as the most appropriate research method. Thanks to the case study, it is possible to confront one's own reasoning with the behaviour of the actual participants of events and processes (Sławińska and Witczak, 2008, p.121). The case study's nature is empirical, it is reliable collection and processing of data that can be compared with each other (Yin, 1994, p.23). It is a research strategy that enables comparing cases between one another.

In order to answer the research questions, the authoress conducted literature research and empirical research - in-depth interviews. The idea is to get detailed opinions and information from the respondents in accordance with the logic of analytical, literal replication.

Information about the in-depth interview:

- the method of an in-depth, semi structured interview method was applied;

- the study consisted of two stages: Stage 1 - answering open-end questions contained in the interview questionnaire; Stage 2 - participants' own conclusions, including the indication of the benefits resulting from the implementation of selected Personal Kaizen principles and instruments in their lives and the assessment of the quality and effectiveness of the personal development process before getting acquainted with Kaizen/Lean and after completing vocational training and acquiring the necessary knowledge about Kaizen/Lean;

- the in-depth interview questionnaire was developed on the basis of a literature analysis and observations carried out by the authoress in a business environment; the questionnaire consisted of 30 open-ended questions divided into three groups;

- 5 participants (Polish managers) took part in the study -3 women and 2 men;

- participants of the study have been working for at least five years in Polish organisations which operate in line with the principles of Kaizen/Lean and they have participated in many training sessions in the area of Kaizen/Lean;

- information about the possibility of participating in the survey was posted on LinkedIn in March 2019, and the survey was conducted at the turn of April and May 2019 (4 telephone interviews, 1 video call using an Internet connection);

- the interviews lasted 1.5 hours on average;

- 18 people expressed their willingness to participate in the study, from among whom, in line with the assumptions, the authoress chose five people who first reported, agreed to carry out a remote conversation with them, as part of a case study, and were available in the period scheduled for conducting the study. 
It is possible that the willingness to participate in the study was expressed only by people who are aware of the importance of implementing the principles and instruments of Personal Kaizen in their personal lives and of the benefits resulting from it. People who do not apply the analysed solutions in their private lives may have deliberately not wanted to participate in the study. In the context of the research questions, however, what was important was to gain knowledge on how to transform Kaizen/Lean principles and instruments to improve the competences of the managers and improve their personal productivity as well as the benefits from implementing Personal Kaizen. The data and information obtained during the study were analysed and they constituted the basis for the formulation of the conclusions.

The purpose of this research is to create initial application assumptions and to pave the way for subsequent, wider research.

\section{HOW MANAGERS USE PERSONAL KAIZEN TO DEVELOP THEIR OWN COMPETENCES AND IMPROVE THEIR PERSONAL PRODUCTIVITY - CASE STUDY}

The interview questionnaires contained the following groups of issues:

\section{Group 1. Introduction to personal development and Personal Kaizen}

- the importance of personal development for the interviewee;

- contact with Kaizen/Lean principles and instruments during vocational training;

- the interviewee's approach to personal development (small steps or large, one-time upsurges) ;

- the private life sphere in which the interviewee applies the Personal Kaizen;

- diagnosis of one's strengths and weaknesses, competences, to take further steps connected with self-development.

\section{Group 2. Personal Kaizen principles and instruments}

- defining values in the life of the interviewee and applying the concept of flow and analysis of personal value streams;

- the importance of the philosophy of minimalism, limiting resources and simplifying in the interviewee's life;

- identifying sources of waste in non-professional life;

- setting measurable goals, supervising them, and their consistent implementation;

- management of personal tasks (methods and instruments); 
- the importance and application of visual management and the role of standardised work in personal life;

- application of the $5 \mathrm{~S}$ method (5 principles of workplace management) in non-professional life - teamwork, having a mentor with whom you could consult your own development, improvement;

- other Personal Kaizen principles and instruments not mentioned previously applied by the interviewee.

\section{Group 3. Support for self-development}

- developing habits;

- the importance of reflection (hansei), self-awareness, feedback, on the path to personal improvement;

- the importance of respect for people, active listening, suspending personal views;

- the importance of relaxation and attention management in a continuous path to excellence;

- approach to life, attitude (positive, negative) and its impact on the process of personal development.

The results of case studying have been presented in Table 1 to Table 5 .

Table 1 - Case 1 (Source: Author)

\begin{tabular}{|l|l|}
\hline Problem group & $\begin{array}{l}\text { Case study } \\
\text { woman, 29 years old, manager, experience with Kaizen/Lean of approx. 9 years }\end{array}$ \\
\hline $\begin{array}{l}\text { Introduction to } \\
\text { personal } \\
\text { development and }\end{array}$ & $\begin{array}{l}\text { - personal development is very important and implemented in Kaizen small steps, } \\
\text { but there are also radical changes (kaikaku), } \\
\text { analysis of return on investment in self-improvement for professional } \\
\text { development, } \\
\text { - areas of Personal Kaizen application: housework, creating habits, continuous } \\
\text { improvement, maintaining order, taking care of the garden and developing its } \\
\text { richness, taking care of own physical condition (regularity), getting rid of bad } \\
\text { habits (e.g. using social networks), } \\
\text { analysis of own strengths and weaknesses (mainly psychological tests), } \\
\text { - planning own personal development based on analysis results, } \\
\text { - training connected with personal development dedicated to managers: } \\
\text { international communication, interpersonal communication, and psychology. }\end{array}$ \\
\hline $\begin{array}{l}\text { Personal Kaizen } \\
\text { principles and } \\
\text { instruments }\end{array}$ & $\begin{array}{l}\text { The participant of the study: } \\
\text { - defines the values in her life (the most important are: family, love, self-fulfilment, } \\
\text { and opportunity for development), } \\
\text { tries to carry out her work in accordance with the principle of flow and analyses } \\
\text { repetitive value streams of values in her life (reflections, without putting them } \\
\text { down), } \\
\text { applies a minimalistic approach to a limited extent, among others in relation to the } \\
\text { clothes she has, mobile phone apps, desktop on the computer, data and }\end{array}$ \\
\hline
\end{tabular}




\begin{tabular}{|c|c|}
\hline Problem group & $\begin{array}{l}\text { Case study } \\
\text { woman, } 29 \text { years old, manager, experience with Kaizen/Lean of approx. } 9 \text { years }\end{array}$ \\
\hline & $\begin{array}{l}\text { information, food, and shopping, } \\
\text { - considers simplifying as very important in her life, it translates into time saving, } \\
\text { - identifies sources of waste in private life; the main sources are: distractions } \\
\text { (wasting time), food, clothing, } \\
\text { - defines goals, but does not put them down (tries to remember them), which causes } \\
\text { problems with supervision and consistent implementation, } \\
\text { - uses kanban in the form of an electronic app, } \\
\text { - applies visual management; examples: kanban for washing, kanban for fireplace } \\
\text { wood, kanban associated with refuelling (sense of security), yellow and colourful } \\
\text { post-it notes, } \\
\text { - uses standardised work; examples: cooking (recipes written down in detail and } \\
\text { according to a set rule), and instructions for the family, } \\
\text { - uses 5S in: the dressing room, kitchen, garage, office, garden, computer, } \\
\text { - as part of teamwork, she occasionally seeks advice of friendly business } \\
\text { psychologists, conducting creative discussions with them, and she has sought } \\
\text { advice of a career counsellor, } \\
\text { - uses other principles and instruments: } 5 \text { Why, cause-and-effect diagram, and risk } \\
\text { analysis. }\end{array}$ \\
\hline $\begin{array}{l}\text { Supporting self- } \\
\text { development }\end{array}$ & $\begin{array}{l}\text { The participant of the study: } \\
\text { - develops habits (very important on the way to improvement), } \\
\text { - tries to learn from mistakes; reflection and feedback, especially after public } \\
\text { speeches, are very important for her, } \\
\text { - is a patient person, for whom active listening is very important, without } \\
\text { comments; she admits, however, that in professional life she has no problems with } \\
\text { it, while privately she is constantly learning this, noticing the potential for } \\
\text { improvement; believes that this approach has changed for better the relationships } \\
\text { in her private life, } \\
\text { - does not use relaxation techniques, but tries to avoid distractions, } \\
\text { - is a person who has a positive attitude to the world around her and respects people. }\end{array}$ \\
\hline $\begin{array}{l}\text { Personal } \\
\text { development } \\
\text { before Personal } \\
\text { Kaizen }\end{array}$ & $\begin{array}{l}\text { - chaos and undefined personal development, } \\
\text { - lack of possibility of supervision and the problem of consistent action, } \\
\text { - worse quality of life and effectiveness of actions. }\end{array}$ \\
\hline $\begin{array}{l}\text { Personal } \\
\text { development in } \\
\text { the Personal } \\
\text { Kaizen spirit }\end{array}$ & $\begin{array}{l}\text { - effective personal development, efficient action and lack of discouragement, } \\
\text { - good habits developed (e.g. regarding physical condition and health), } \\
\text { - order, there is no need to search for things, } \\
\text { - effective task management, } \\
\text { - improvement in the sphere of self-discipline, assertiveness, self-control, } \\
\text { - change of approach to personal development and lasting effects, } \\
\text { - improvement of the quality of personal life, free time, improvement of health. }\end{array}$ \\
\hline
\end{tabular}




\section{Table 2 - Case 2 (Source: Author)}

\begin{tabular}{|c|c|}
\hline Problem group & $\begin{array}{l}\text { Case study } \\
\text { woman, } 44 \text { years old, manager, experience with Kaizen/Lean of approx. } 7 \text { years }\end{array}$ \\
\hline $\begin{array}{l}\text { Introduction to } \\
\text { personal } \\
\text { development and } \\
\text { Personal Kaizen }\end{array}$ & $\begin{array}{l}\text { - personal development is very important and implemented in small Kaizen steps, } \\
\text { but mainly in the case of children's development, } \\
\text { - areas of applying Personal Kaizen: housework, bringing up children; planned } \\
\text { areas: sport, } \\
\text { - periodic analysis of own strengths and weaknesses, } \\
\text { - training related to personal development dedicated to managers: problem solving } \\
\text { and post-graduate studies. }\end{array}$ \\
\hline $\begin{array}{l}\text { Personal Kaizen } \\
\text { principles and } \\
\text { instruments }\end{array}$ & $\begin{array}{l}\text { The participant of the study: } \\
\text { - has not defined the values in her life, she does not apply the principles of flow and } \\
\text { has not analysed repetitive value streams in her own life, } \\
\text { - applies a minimalistic approach to, among others, towards resources available, and } \\
\text { simplification is very important in her life, } \\
\text { - identifies sources of waste in her private life; the main source is wasting time; } \\
\text { draws attention to environmental waste (decision to limit the purchase of products } \\
\text { in plastic packaging), } \\
\text { - defines and puts down measurable goals, oversees and consistently implements } \\
\text { them, } \\
\text { - uses an electronic calendar and a planner, common for all family members, to } \\
\text { manage tasks, } \\
\text { - applies visual management; examples: planner, calendar, visual instructions for } \\
\text { the children (as part of standardised work), visual marking of cabinets in the } \\
\text { children's room, } \\
\text { - applies } 5 \mathrm{~S} \text { in: the dressing room, kitchen, children's room; she sorts things mainly } \\
\text { before Christmas, } \\
\text { - occasionally seeks advice as part of teamwork. }\end{array}$ \\
\hline $\begin{array}{l}\text { Supporting self- } \\
\text { development }\end{array}$ & $\begin{array}{l}\text { The participant of the study: } \\
\text { - develops habits, mainly food-related ones, but also related to learning languages } \\
\text { (uses reminder apps), } \\
\text { - tries to learn from mistakes; reflection and feedback are very important, } \\
\text { - active listening is important to her; she believes that this approach has changed } \\
\text { relationships in her private life for the better, } \\
\text { - does not regularly use relaxation techniques, time spent traveling to work and } \\
\text { home is time for making reflections, } \\
\text { - is a person with a positive attitude towards the world and respects people, } \\
\text { - works actively on developing creativity. }\end{array}$ \\
\hline $\begin{array}{l}\text { Personal } \\
\text { development } \\
\text { before Personal } \\
\text { Kaizen }\end{array}$ & $\begin{array}{l}\text { - chaos, } \\
\text { - unspecified personal development, } \\
\text { - greater garbage production, } \\
\text { - worse quality of life and effectiveness of actions. }\end{array}$ \\
\hline $\begin{array}{l}\text { Personal } \\
\text { development in } \\
\text { the Personal } \\
\text { Kaizen spirit }\end{array}$ & $\begin{array}{l}\text { - self-consciousness and an organised life, } 5 \mathrm{~S} \text { in resources, } \\
\text { - systemic approach to personal development and goal and task management, } \\
\text { - this period is for her "another universe", } \\
\text { - permanent effects, } \\
\text { - improving the quality of personal life and more free time. }\end{array}$ \\
\hline
\end{tabular}


Table 3 - Case 3 (Source: Author)

\begin{tabular}{|c|c|}
\hline Problem group & $\begin{array}{l}\text { Case study } \\
\text { woman, } 33 \text { years old, manager, experience with Kaizen/Lean of approx. } 5 \text { years }\end{array}$ \\
\hline $\begin{array}{l}\text { Introduction to } \\
\text { personal } \\
\text { development and } \\
\text { Personal Kaizen }\end{array}$ & $\begin{array}{l}\text { - personal development is very important, but it is mainly based on large-scale } \\
\text { upsurges, } \\
\text { - areas of Personal Kaizen application: housework, bringing up children; } \\
\text { eliminating unnecessary activities through modernisation of resources (automatic } \\
\text { clothes dryer and dishwasher), goals in the spirit of kata (Toyota Kata), } \\
\text { - no diagnosis of strengths and weaknesses and additional training. }\end{array}$ \\
\hline $\begin{array}{l}\text { Personal Kaizen } \\
\text { principles and } \\
\text { instruments }\end{array}$ & $\begin{array}{l}\text { The participant of the study: } \\
\text { - has defined values in her life, applies the principles of flow and has analysed } \\
\text { repetitive value streams in her own life (without putting them down), } \\
\text { - applies a minimalistic approach to: toys, equipment, crockery, food, friends with a } \\
\text { negative attitude to life, } \\
\text { - considers simplification as very important in her life, } \\
\text { - identifies sources of waste in her private life; the main ones are: creating garbage, } \\
\text { wasting time, doing the washing (after putting on the clothes once they are } \\
\text { immediately put away to be washed), } \\
\text { - defines and records measurable goals in the kata spirit; a slight problem with the } \\
\text { consistent pursuit of their implementation; the main goal is to maximise the time } \\
\text { spent with the family, } \\
\text { - uses an electronic calendar to manage tasks, } \\
\text { - applies visual management; examples: visual instructions for her child (as part of } \\
\text { standardised work), } \\
\text { - uses } 5 \mathrm{~S} \text { in: the children's room, dressing room, documents, } \\
\text { - as part of teamwork, she occasionally seeks advice of her brother, who at the same } \\
\text { time has a motivating impact on her. }\end{array}$ \\
\hline $\begin{array}{l}\text { Supporting self- } \\
\text { development }\end{array}$ & $\begin{array}{l}\text { The participant of the study: } \\
\text { - has a problem with developing habits, } \\
\text { - tries to learn from her mistakes; reflection and feedback are very important for her } \\
\text { (she herself first gives positive and then negative feedback), } \\
\text { - active listening is important to her, but it is something with room for } \\
\text { improvement; however, she believes that the change in approach has impacted } \\
\text { improvement of relationships in her private life, } \\
\text { - does not regularly apply relaxation techniques, } \\
\text { - is a person with a rather positive attitude towards the world and she respects } \\
\text { people, believes that it is of great importance for building positive and effective } \\
\text { relationships, } \\
\text { - actively works on developing her creativity. }\end{array}$ \\
\hline $\begin{array}{l}\text { Personal } \\
\text { development } \\
\text { before Personal } \\
\text { Kaizen }\end{array}$ & $\begin{array}{l}\text { - worse relationships, } \\
\text { - chaos, } \\
\text { - losses connected with generating waste, } \\
\text { - worse quality of life and effectiveness of actions. }\end{array}$ \\
\hline $\begin{array}{l}\text { Personal } \\
\text { development in } \\
\text { the Personal } \\
\text { Kaizen spirit }\end{array}$ & $\begin{array}{l}\text { - positive attitude, } \\
\text { - orderly life and resources, pursuing goals, } \\
\text { - more lasting results, } \\
\text { - less waste, } \\
\text { - improvement of the quality of personal life and more free time. }\end{array}$ \\
\hline
\end{tabular}




\section{Table 4 - Case 4 (Source: Author)}

\begin{tabular}{|c|c|}
\hline Problem group & $\begin{array}{l}\text { Case study: } \\
\text { man, } 42 \text { years old, manager, experience with Kaizen/Lean of approx. } 6 \text { years }\end{array}$ \\
\hline $\begin{array}{l}\text { Introduction to } \\
\text { personal } \\
\text { development and } \\
\text { Personal Kaizen }\end{array}$ & $\begin{array}{l}\text { - personal development is important, mainly in the Kaizen spirit, } \\
\text { - areas of applying Personal Kaizen: organised learning, garage, dressing room, } \\
\text { - no diagnosis of own strengths and weaknesses and no additional training. }\end{array}$ \\
\hline $\begin{array}{l}\text { Personal Kaizen } \\
\text { principles and } \\
\text { instruments }\end{array}$ & $\begin{array}{l}\text { The participant of the study: } \\
\text { - has defined values in his life, but he does not apply the flow principle and has not } \\
\text { analysed repetitive streams of values, } \\
\text { - applies a minimalistic approach to: shopping, } \\
\text { - considers simplification to be very important in his life, } \\
\text { - identifies sources of waste in his private life; the main sources are: food, clothes, } \\
\text { children's toys, } \\
\text { - defines, but does not put down his goals, problem with supervision, lack of } \\
\text { consistency, } \\
\text { - uses an electronic calendar to manage his tasks, } \\
\text { - applies visual management; examples: yellow post-it notes, colour markers, } \\
\text { - does not use standardized work, } \\
\text { - applies } 5 \mathrm{~S} \text { in: tools, clothes, documents, children's toys, } \\
\text { - does not seek advice and works alone. }\end{array}$ \\
\hline $\begin{array}{l}\text { Supporting self- } \\
\text { development }\end{array}$ & $\begin{array}{l}\text { The participant of the study: } \\
\text { - has a problem with developing habits, } \\
\text { - tries to learn from his mistakes; } \\
\text { - has not thought about reflection and feedback in his life, and active listening is a } \\
\text { field for improvement, } \\
\text { - does not regularly apply relaxation techniques, } \\
\text { - is a person with a rather positive attitude towards the world and respects people, } \\
\text { - he does not work on developing creativity; he has never thought about it. }\end{array}$ \\
\hline $\begin{array}{l}\text { Personal } \\
\text { development } \\
\text { before Personal } \\
\text { Kaizen }\end{array}$ & $\begin{array}{l}\text { - mess in documents, tools, always looking for something, } \\
\text { - chaos, } \\
\text { - losses associated with waste generation, } \\
\text { - worse quality of life and effectiveness of activities. }\end{array}$ \\
\hline $\begin{array}{l}\text { Personal } \\
\text { development in } \\
\text { the Personal } \\
\text { Kaizen spirit }\end{array}$ & $\begin{array}{l}\text { - everything in its place ("I use instead of looking for it"), } \\
\text { - more orderly life and striving for the implementation of life plans, } \\
\text { - less waste, } \\
\text { - improvement of the quality of personal life, more free time, } \\
\text { - the interviewee, however, still has considerable potential for improvement. }\end{array}$ \\
\hline
\end{tabular}




\section{Table 5 - Case 5 (Source: Author)}

\begin{tabular}{|c|c|}
\hline Problem group & $\begin{array}{l}\text { Case study } \\
\text { man, } 38 \text { years old, manager, experience with Kaizen/Lean of approx. } 12 \text { years }\end{array}$ \\
\hline $\begin{array}{l}\text { Introduction to } \\
\text { personal } \\
\text { development and } \\
\text { Personal Kaizen }\end{array}$ & $\begin{array}{l}\text { - personal development is very important and mainly consisting of small step } \\
\text { improvement (Kaizen), } \\
\text { - areas of Personal Kaizen application in personal life: everywhere, } \\
\text { - the interviewee has diagnosed his strengths and weaknesses, } \\
\text { - the interviewee has undergone additional training, mainly soft training. }\end{array}$ \\
\hline $\begin{array}{l}\text { Personal Kaizen } \\
\text { principles and } \\
\text { instruments }\end{array}$ & $\begin{array}{l}\text { The participant of the study: } \\
\text { - has defined values in his life, applies principles of flow in scientific development } \\
\text { and implementation of tasks, he has also analysed the value streams associated } \\
\text { with his development, } \\
\text { - applies a minimalistic approach to: shopping, food, data, and information, } \\
\text { considers simplification as something of great importance in his life, } \\
\text { - identifies sources of waste in his private life; the main sources are: food, clothes, } \\
\text { organised meetings, because it seems the thing to do, } \\
\text { - defines and puts down the goals, supervises and consistently implements them, } \\
\text { - uses a personal kanban and an electronic calendar to manage tasks, } \\
\text { - applies visual management; examples: kanbans, pictorial markings, colour binders, } \\
\text { shadow boards for tools, } \\
\text { - uses standardized but informal work, } \\
\text { - applies 5S in: information, tools, clothes, and documents, } \\
\text { - seeks advice, but often works independently, } \\
\text { - introduced the principles of Total Productive Maintenance (TPM) for household } \\
\text { appliances and private cars as well as the Single Minute Exchange of Die (SMED) } \\
\text { in connection with daily dressing up. }\end{array}$ \\
\hline $\begin{array}{l}\text { Supporting self- } \\
\text { development }\end{array}$ & $\begin{array}{l}\text { The participant of the study: } \\
\text { - develops habits, the most difficult are regular, healthy meals, sports, } \\
\text { - tries to learn from his mistakes; values reflection and feedback, } \\
\text { - active listening is a field for improvement for him, } \\
\text { - does not regularly use relaxation techniques (occasionally), but plans to change } \\
\text { this, } \\
\text { - is a person with a positive attitude towards the world and he respects people, } \\
\text { - is not working on developing creativity, he has never given a thought to it, but he } \\
\text { has been curious about it. }\end{array}$ \\
\hline $\begin{array}{l}\text { Personal } \\
\text { development } \\
\text { before Personal } \\
\text { Kaizen }\end{array}$ & $\begin{array}{l}\text { - disorder mainly in his mind, but also in resources, constantly looking for } \\
\text { something, } \\
\text { - losses related to the generation of waste, } \\
\text { - problem with habits, } \\
\text { - doing many things at the same time, } \\
\text { - worse quality of life and effectiveness of activities. }\end{array}$ \\
\hline $\begin{array}{l}\text { Personal } \\
\text { development in } \\
\text { the Personal } \\
\text { Kaizen spirit }\end{array}$ & $\begin{array}{l}\text { - order, no need to look for things, } \\
\text { - finally implementing his goals, } \\
\text { - does not have to think about what else needs to be done by him, he has an effective } \\
\text { system of managing tasks and noting down ideas, } \\
\text { - less waste, } \\
\text { - improving the quality of personal life and more free time. }\end{array}$ \\
\hline
\end{tabular}


Managers working in the Kaizen/Lean environment, participating in numerous training sessions covering both the principles and instruments of continuous improvement, simplification, and minimising resources, try to transfer the knowledge acquired during training to their personal lives. The participants of the study positively assessed the solutions taken from training and implemented in their personal lives. At the same time, they pointed out that this has significantly improved and organised their work on acquiring new knowledge and skills, and positively influenced the quality of life. Knowledge about reflection, respect for people, active listening made them realise how many mistakes they had been making in their relationship with their closest ones.

The results of the literature query carried out and the qualitative research conducted among Polish managers allow for formulating the following conclusions:

- managers transform the knowledge acquired during training undergone during their professional work into their private life;

- a number of principles and instruments of the Kaizen philosophy and Lean Management concepts can be distinguished, which find their application in supporting the process of developing professional and non-professional competences of a human being; we can define the set of such principles and instruments as the Personal Kaizen approach;

- managers most often transform the following principles and instruments into non-professional life: continuous improvement implemented in small steps, defining human-related values, identifying sources of waste, limiting the amount of resources held and processed, 5S, visual management (including kanban), work standardisation, and developing habits;

- the managers highlight that individual principles and instruments are often dependent on one another and the selection of one of them determines the necessity of applying the next one;

- the most frequently indicated sources of waste are: throwing away food, unnecessary purchases (clothes, equipment, children's toys); the most wasted resource, according to the managers, is time;

- the managers spend too little time on rest, do not use relaxation methods, attention management, improving concentration, and developing creativity;

- an interesting thing is the implementation of TPM principles to maintain good condition of devices and vehicles at home, as well as SMED principles for everyday changeovers, namely dressing up for work in the morning. 


\section{CONCLUSION}

Living in a knowledge-based economy, we must constantly develop. Managers are aware of the fact that if they stop, they really begin to step back. In order for them to develop, they must find time for it, for example by improving their productivity. The goal of Lean Managers is to work smarter, not harder, and as a result, do scheduled work faster. Management sciences offer a whole spectrum of principles and instruments to improve the organisation, its structures, processes, and systems. By transforming them into our personal lives, we can improve our work, find time for development and rest, and thus improve the quality of our lives and develop our competences.

The analysis of literature and case studies carried out were aimed at obtaining answers to the research questions posed at the beginning and verifying the formulated hypotheses.

All managers participating in the study have declared transforming selected Kaizen/Lean principles and instruments into their private lives. It follows that there are Polish managers working in the Kaizen/Lean environment, benefiting from Lean Management systems and choosing an improvement path based on a series of small steps in order to develop their competences and improve the quality of their lives. The $H I$ hypothesis has been confirmed.

In the case study, the managers pointed out, among others, the following examples of the benefits of implementing Personal Kaizen in their lives:

- order, no need to look for things,

- effective task management,

- less waste,

- improving the quality of personal life, more free time,

- self-consciousness and orderly life,

- systemic approach to personal development, visible effects,

- the use of small steps, resulting in lasting effects,

- effective action and lack of discouragement,

- good habits developed (e.g. regarding physical condition and health),

- improvement in the sphere of self-discipline, assertiveness, self-control, and relationships in the family.

As it follows from the above, managers, implementing the principles and instruments of Personal Kaizen achieve specific benefits, which confirms the $H 2$ hypothesis.

A compilation of the research questions, research hypotheses, and results of verification of the research hypotheses has been presented in Table 6 . 
The goal of the study conducted has been to identify the benefits of implementing Personal Kaizen and cannot be the basis for generalisation. The set of principles and tools proposed by the authoress constitutes a framework for personal improvement and can be a guidepost for all those for whom personal development, increasing competences, and improving the quality of life are of importance. It may also be an inspiration for personal development. Small steps allow for achieving lasting results, and a wide range of flexible instruments allows for choosing those that meet personalised needs. In the respondents' opinion, the fact of participating in the Lean and Kaizen projects contributed to a different perception of waste, realising the amount of time and resources wasted, the need for continuous improvement, changing the approach to problems and the way they are solved, cooperating with household members, willingness to develop thriftiness habits, maintaining order and better organisation of activities in personal life.

Table 6 - Verification of the Hypotheses (Source: Author)

\begin{tabular}{|c|c|c|}
\hline Research question & Hypothesis & Hypothesis verification \\
\hline $\begin{array}{l}\text { RQ1. How and in what way do } \\
\text { Polish managers use the } \\
\text { knowledge gained within their } \\
\text { professional work on } \\
\text { Kaizen/Lean Management to } \\
\text { develop competences in their } \\
\text { personal lives and improve their } \\
\text { personal productivity? }\end{array}$ & $\begin{array}{l}\text { H1. Polish managers working in } \\
\text { the Kaizen/Lean environment, } \\
\text { benefit from the knowledge on } \\
\text { the principles and instruments of } \\
\text { Kaizen/Lean Management gained } \\
\text { during their professional work, to } \\
\text { develop competences in their } \\
\text { personal lives and improve } \\
\text { personal productivity. }\end{array}$ & $\begin{array}{l}5 \text { people participated in the study } \\
\text { and } 18 \text { people applied. Each of } \\
\text { the interviewees declared } \\
\text { applying selected Kaizen/Lean } \\
\text { Management principles and } \\
\text { instruments in the process of } \\
\text { developing their own } \\
\text { competences. } \\
\text { The interviewees declared that } \\
\text { the application of Kaizen/Lean } \\
\text { Management principles and } \\
\text { instruments in their personal } \\
\text { lives has significantly improved } \\
\text { their personal productivity. } \\
\text { The hypothesis has been } \\
\text { confirmed. }\end{array}$ \\
\hline $\begin{array}{l}\text { RQ2. What benefits do Polish } \\
\text { managers achieve from } \\
\text { implementing Personal Kaizen in } \\
\text { their personal lives? }\end{array}$ & $\begin{array}{l}\mathrm{H} 2 \text {. Polish managers achieve } \\
\text { specific benefits related to using } \\
\text { the Personal Kaizen approach in } \\
\text { their personal lives. }\end{array}$ & $\begin{array}{l}\text { Polish managers declare } \\
\text { achieving specific benefits } \\
\text { connected with the use of } \\
\text { Personal Kaizen principles and } \\
\text { instruments in their personal } \\
\text { lives. These benefits have been } \\
\text { indicated in points } 4 \text { and } 5 \text { of this } \\
\text { article. } \\
\text { The hypothesis has been } \\
\text { confirmed. }\end{array}$ \\
\hline
\end{tabular}


During the study, the participants repeatedly stated that they had just realised that they could improve something and discovered further areas with room for improvement in their personal lives yet. They suggest that it is worth promoting the assumptions and instruments of the Lean and Kaizen approach (the so-called Personal Kaizen Toolbox, mentioned in point 2 of the study) in order to reduce waste in all activities. The research results can constitute a benchmark for managers and they are illustrative, application and inspirational.

As part of further research, it is worth expanding its scope by next instruments and subsequent analysed cases. This will allow for to creating a set of Personal Kaizen Toolbox instruments, and maybe a diagnosis sheet for the current level of the manager's personal thriftiness.

\section{REFERENCES}

Baccarani, C., Mascherpa, V. and Minozzo, M., 2013. Zen and well-being at the workplace. The TQM Journal, [e-journal] 25(6), pp.606-624. DOI: 10.1108/TQM-07-2013-0077.

Bicheno, J. and Holweg, M., 2009. The Lean Toolbox: The essential Guide to Lean Transformation. $5^{\text {th }}$ Ed. Buckingham: PICSIE Books.

Drucker, P.F., 2005. Managing Oneself. Harvard Business Review. [online] Available at: <https://hbr.org/2005/01/managing-oneself> [Accessed 14 July 2020].

Emiliani, M.L., 1998a. Continuous personal improvement. Journal of Workplace Learning, [e-journal] 10(1), pp.29-38. DOI: 10.1108/13665629810370021.

Emiliani, M.L., 1998b. Lean behaviors. Management Decision, [e-journal] 36(9), pp.615-631. DOI: 10.1108/00251749810239504.

Garvin, D.A., 1993. Building a Learning Organization. Harvard Business Review, 71(4), pp.78-91.

Graban, M., 2011. Lean Hospitals: Improving Quality, Patient Safety, and Employee Engagement. $2^{\text {nd }}$ Ed. Wrocław: ProdPublishing.

Imai, M., 2006. Gemba Kaizen: A Commonsense, Low-Cost Approach to Management. Warsaw: MT Biznes Publishing.

Imai, M., 2007. Kaizen: The Key to Japan's Competitive Success. Warsaw: MT Biznes Publishing.

Keating, C., Backholer, K. and Peeters, A., 2014. Prevalence of overweight and obesity in children and adults. The Lancet, 384, pp.2107-2108.

Liker, J.K. and Hoseus, M., 2009. Toyota Culture. Warsaw: MT Biznes Publishing. 
Liker, J.K. and Meier, D.P., 2011. The Toyota Way Fieldbook. Warsaw: MT Biznes Publishing.

Liker, K.L., 2005. The Toyota Way: 14 Management Principles of The Toyota Way. Warsaw: MT Biznes Publishing.

Locher, D., 2012. Lean Office and Service Simplified: The Definitive How-To Guide. Warsaw: MT Biznes Publishing.

Markovitz, D., 2011. A factory of one. Boca Raton: CRC Press Taylor \& Francis Group.

Maurer, R., 2007. One Small Step Can Change Your Life: The Kaizen Way. Gliwice: HELION.

Maurer, R., 2016. The Spirit of Kaizen: Creating Lasting Excellence One Small Step at a Time: Creating Lasting Excellence One Small Step at a Time. Gliwice: HELION.

Roberts, CH., and McDonald, G., 1995. Training to fail. Journal of Management Development, 14(4), pp.16-31.

Sławińska, M. and Witczak, H., 2008. Methodological basis of doctoral theses in economic sciences. Warsaw: PWE.

Stoller, J., 2015. The Lean CEO: Leading the Way to World-Class Excellence. Warsaw: MT Biznes Publishing.

Suarez-Barraza, M.F., Ramis-Pujol, J. and Dahlgaard-Park, S., 2013. Changing quality of life through the Personal kaizen approach: a qualitative study. International Journal of Quality and Service Science, [e-journal] 5(2), pp.191207. DOI: 10.1108/IJQSS-03-2013-0015.

Womack, J.P. and Jones, D.T., 2008. Lean thinking: Banish Waste and Create Wealth in Your Corporation, Revised and Updated. Wrocław: ProdPress.com.

Yin, R.K., 1994. Case Study Research. Design and Methods. Newbury Park: Sage Publication.

Yoneyama, E., 2007. Phenomenology of life, Zen and management. Society and Business Review, [e-journal] 2(2), pp.204-217. DOI: 10.1108/17465680710757411.

\section{ABOUT THE AUTHOR}

Iwona Burka - Katowice Business University (GWSH Górnośląska Wyższa Szkoła Handlowa), Poland, Faculty of Management, PhD., e-mail: iwonaburka@efektywnosc.net.pl, Author's ORCID: 0000-0002-7338-8830. 


\section{CONFLICTS OF INTEREST}

The author declares no conflict of interest. The funder had no role in the design of the study; in the collection, analyses, or interpretation of data; in the writing of the manuscript, or in the decision to publish the results.

(C) 2020 by the authors. Submitted for possible open access publication under the terms and conditions of the Creative Commons Attribution (CC-BY) license (http://creativecommons.org/licenses/by/4.0/). 